\title{
A case of Giant Perifollicular Fibroma - a Diagnostic Challenge
}

\author{
Raghavendra RAO'1, Srilatha PARAMPALLI SRINIVAS², Varsha M. SHETTY1 \\ ${ }^{1}$ Department of Dermatology, Kasturba Medical College, Manipal Academy of Higher Education, Karnataka, India \\ ${ }^{2}$ Department of Pathology, Kasturba Medical College, Manipal Academy of Higher Education, Karnataka, India
}

Correspondence: Varsha M. Shetty, E-mail: varshams18@gmail.com

UDC 616.594-006-056.7-091.8

\begin{abstract}
Perifollicular fibroma (PFF) is a rare proliferative lesion originating from the perifollicular connective tissue sheath. It may be congenital or acquired manifesting as skin colored to pink, asymptomatic papules of 1-5 mm in size. They are commonly distributed in the head and neck region. Multiple PFFs may be associated with internal malignancy or as a part of Birt-Hogg-Dube syndrome. Histopathology serves as an essential tool in clinching the diagnosis. Herein we report a case of giant congenital PFF.
\end{abstract}

Key words: Fibroma; Hair Follicle; Skin Diseases; Facial Neoplasms; Diagnosis; Hamartoma; Dermoscopy; Case Reports

\section{Introduction}

Perifollicular fibroma (PFF) is an uncommon cutaneous hamartoma arising from the connective tissue sheath surrounding the hair follicles. It characteristically presents as solitary or multiple skin colored, dome shaped papules measuring $1-5 \mathrm{~mm}$ in diameter. It is usually distributed in the head and neck area. Multiple PFFs are usually associated with coIonic polyps and internal malignancy. The etiology of PFF is still doubtful with few studies suggesting them to be neoplastic in nature and few proposing its inflammatory origin (1, 2). Histopathology is crucial in confirming the diagnosis and differentiating it from other conditions. Herein we report a case of giant congenital PFF with characteristic histopathology features.

\section{Case Report}

A 49-year old female presented with the complaints of an asymptomatic lesion on the right cheek being there since her birth. The
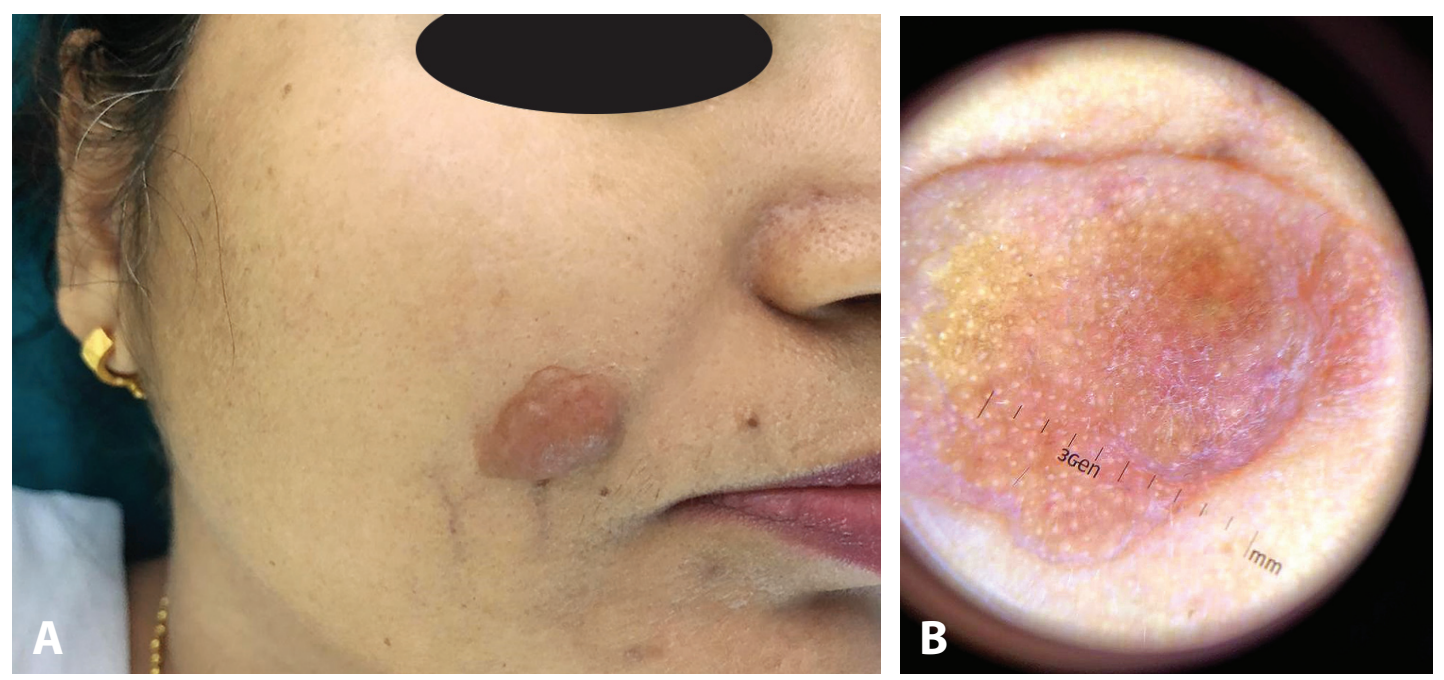

Figures 1 A and B. (A) Clinical picture - A solitary reddish brown, firm, well-defined plaque on the right cheek. (B) Dermoscopy showing multiple follicular openings with areas of pallor 

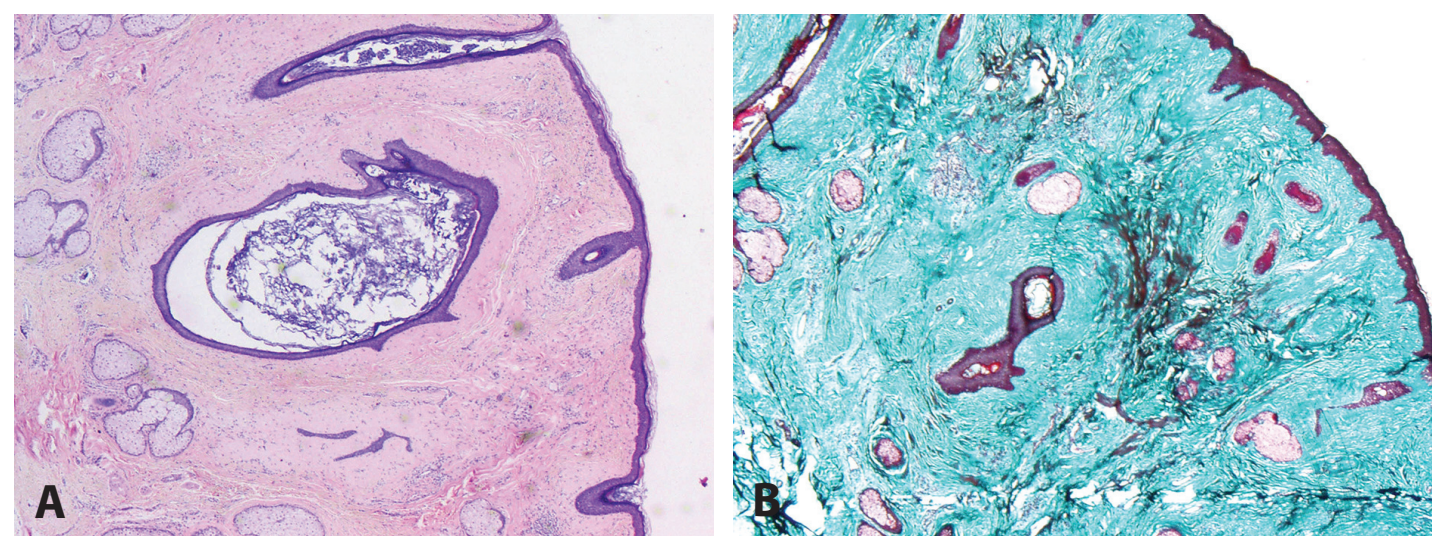

Figures 2 A and B. (A) Histopathological section showing follicular plugging with perifollicular concentrically arranged collagen bundles (H \& E, 100X). (B) Masson's Trichrome staining highlighting perifollicular collagen bundles (100X)

lesion progressively increased in size over the initial few years of life and then stopped progressing further. Her past medical history and family history were unremarkable. Physical examination revealed a solitary, reddish brown, firm plaque on the right cheek just above the nasolabial fold. It was non-tender, $9 \mathrm{~mm} \times 6 \mathrm{~mm}$ in size, and on close inspection it showed dilated blood vessels on its surface. (Figure 1a). Dermoscopic examination revealed central area of pallor with numerous follicular openings (Figure 1b).

The lesion was subjected to excisional biopsy which revealed keratinized thinned out epidermis with follicular plugging. Dermis showed collagen bundles arranged concentrically around normal looking hair follicles along with few scattered thinned out blood vessels. A focal lymphocytic infiltrate was also observed. Masson's Trichrome staining was done to highlight the perifollicular collagen bundles (Figures 2a, 2b). However, the staining for elastic tissue was negative. Thus, it was diagnosed as a case of perifollicular fibroma.

\section{Discussion}

PFF is a rare cutaneous hamartoma arising from the perifollicular connective tissue sheath. It was first described by Burnier and Rejsek in 1925. They may be congenital or acquired in nature, presenting as asymptomatic, solitary or multiple skin colored to pink, firm papules measuring $1-5 \mathrm{~mm}$ in diameter. PFF s are commonly found to be distributed in the head and neck region (1). Multiple PFFs are seen to be associated with colonic polyps, in- ternal malignancy, and bronchiectasis (2). PFF may also occur in association with other benign tumors such as fibrofolliculoma, trichodiscoma and acrochordon as a part of Birt-Hogg-Dube syndrome, which is an autosomal dominant condition (3). The etiopathogenesis of PFF is still unclear with few studies suggesting it to be neoplastic in nature while others reporting it to be an exaggerated fibroblastic response to unknown inflammatory triggers $(1,2)$.

On histopathology, PFF exhibits concentric layers of ribbon-like collagen bundles around a normal hair follicle giving an onion skin appearance. There is an artifactual cleft that is observed separating the fibroma from the adjacent connective tissue (2). However, the histopathological changes are not seen uniformly across all hair follicles; hence, serial sectioning is important in clinching the diagnosis (4). The common differentials for PFF are fibrofolliculoma, trichodiscoma, dermatofibroma and neurofibroma (1). Though PFF, fibrofolliculoma and trichodiscoma are clinico-pathologically distinct entities, few authors have proposed to consider them as a part of a common spectrum. Fibrofolliculoma is known to show epithelial component in the form of thin anastomosing strands surrounded by a prominent mesenchymalstroma. Trichodiscoma, on the other hand, has a less prominent epithelial component with a marked myxofibrovascularstroma (5). Few authors believe PFF to be a variant of angiofibroma; however, angiofibromas are known to lack concentric perifollicular fibrosis and instead show stellate fibroblasts with increased blood vessels (6). 
On immunohistochemistry (IHC), there are CD34 positive spindle cells distributed diffusely and scattered factor XIIla positive dendritic cells within the connective tissue sheath in PFF (7). In our case, IHC was not done in view of financial constraints. We observed a central area of pallor surrounded by follicular openings on dermoscopic examination; however, we could not establish its significance as there are no reports describing the dermoscopic features of PFF so far.

This case aims to highlight the fact that PFF is a rare condition and the occurrence of a giant solitary PFF as in our case has not been reported so far. It is important for dermatologists to consider PFF as one of the differentials for solitary skin colored papulonodule on the head and neck.

\author{
Abbreviations \\ PFF - Perifollicular fibroma \\ IHC - immunohistochemistry
}

\section{References}

1. Nam JH, Min JH, Lee GY, Kim WS. A case of perifollicular fibroma. Ann Dermatol. 2011;23(2):236-8.

2. Cho S, Hahm JH. Perifollicular fibroma. J Eur Acad Dermatol Venereol. 1999;13(1):46-9.

3. McKenna DB, Barry-Walsh C, Leader M, Murphy GM. Multiple perifollicular fibromas. J Eur Acad Dermatol Venereol. 1999;12(3):234-7.

4. Ogawa E, Okuyama R, Tagami H, Aiba S. Perifollicular fibroma: a case successfully diagnosed with deeply cut sections. J Dermatol. 2008;35(2):126-8.

5. Ho J, Bhawan J. Folliculosebaceous neoplasms: a review of clinical and histological features. J Dermatol. 2017;44(3):259-78.

6. Shvartsbeyn M, Mason AR, Bosenberg MW, Ko CJ. Perifollicular fibroma in Birt-Hogg-Dubé syndrome: an association revisited. J Cutan Pathol. 2012;39(7): 675-9.

7. Misago N, Kimura T, Narisawa Y. Fibrofolliculoma/ trichodiscoma and fibrous papule (perifollicular fibroma/angiofibroma): a revaluation of the histopathological and immunohistochemical features. J Cutan Pathol. 2009;36(9):943-51.

\section{Slučaj gigantskog perifolikularnog fibroma - dijagnostički izazov}

\section{Sažetak}

Perifolikularni fibrom je retka proliferativna lezija koja nastaje iz omotača perifolukularnog vezivnog tkiva. Može biti urođen ili stečen, a manifestuje se kao koža obojena u roza, asimptomatske papule su veličine od 1 do $5 \mathrm{~mm}$ obično se nalaze na glavi i vratu. Višestruki perifolikularni fibromi mogu biti udruženi sa internim malignitetom ili kao deo Birt-Hogg-Dube sindroma. Histopotologija je bitna u postavljanju dijagnoze. Ovde prikazujemo slučaj gigantskog urođenog perifolikularnog fibroma.

Ključne reči: Fibrom; Folikul dlake; Kožne bolesti; Neoplazme lica; Dijagnoza; Hamartom; Dermoskopija; Prikazi slučajeva

Received 12.12.2019.

Accepted 16.01.2020. 